San Jose State University

SJSU ScholarWorks

Master's Theses

Master's Theses and Graduate Research

1994

\title{
An analysis of the effect of state and local bureaucratic regulation on the viability of small business within Santa Clara County
}

Leslee Allyson Brady

San Jose State University

Follow this and additional works at: https://scholarworks.sjsu.edu/etd_theses

\section{Recommended Citation}

Brady, Leslee Allyson, "An analysis of the effect of state and local bureaucratic regulation on the viability of small business within Santa Clara County" (1994). Master's Theses. 892.

DOI: https://doi.org/10.31979/etd.hf9n-dumf

https://scholarworks.sjsu.edu/etd_theses/892

This Thesis is brought to you for free and open access by the Master's Theses and Graduate Research at SJSU ScholarWorks. It has been accepted for inclusion in Master's Theses by an authorized administrator of SJSU ScholarWorks. For more information, please contact scholarworks@sjsu.edu. 


\section{INFORMATION TO USERS}

This manuscript has been reproduced from the microfilm master. UMI films the text directly from the original or copy submitted. Thus, some thesis and dissertation copies are in typewriter face, while others may be from any type of computer printer.

The quality of this reproduction is dependent upon the quality of the copy submitted. Broken or indistinct print, colored or poor quality illustrations and photographs, print bleedthrough, substandard margins, and improper alignment can adversely affect reproduction.

In the unlikely, event that the author did not send UMI a complete manuscript and there are missing pages, these will be noted. Also, if unauthorized copyright material had to be removed, a note will indicate the deletion.

Oversize materials (e.g., maps, drawings, charts) are reproduced by sectioning the original, beginning at the upper left-hand corner and contimuing from left to right in equal sections with small overlaps. Each original is also photographed in one exposure and is included in reduced form at the back of the book.

Photographs included in the original manuscript have been reproduced xerographically in this copy. Higher quality $6^{n} \times 9^{n}$ black and white photographic prints are available for any photographs or illustrations appearing in this copy for an additional charge. Contact UMI directly to order.

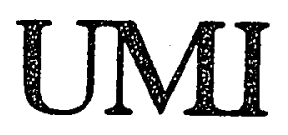


AN ANALYSIS OF THE EFFECT OF STATE AND LOCAL BUREAUCRATIC REGULATION ON THE VIABILITY OF SMALL BUSINESS WITHIN SANTA CLARA COUNTY.

\author{
A Thesis \\ Presented to \\ The Faculty of the Department of Economics \\ San Jose State University
}

In Partial Fulfillment

of the Requirements for the Degree

Master of Arts

by

Leslee Allyson Brady

December, 1994 
UMI Number: 1361150

Copyright 1994 by Brady, Leslee Allyson

All rights reserved.

UfisI Hicroform Edition 1361150

Copyright 1995, by UMI Company. All rights reserved.

This microform edition is protected against unauthorized copying under Title 17, United States code.

\section{UMI}

300 North Zeeb Road

Ann Arbor, MI 48103 
(C) 1994

Leslee Allyson Brady

ALL RIGHTS RESERVED 
APPROVED FOR THE DEPARTMENT OF ECONOMICS

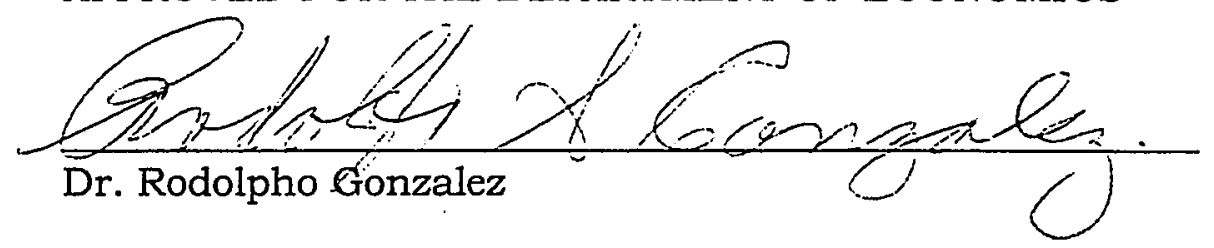

Thane Water

Dr. Thayer Watkins

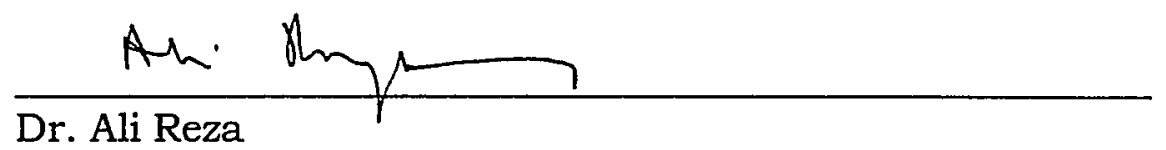

APPROVED FOR THE UNIVERSITY

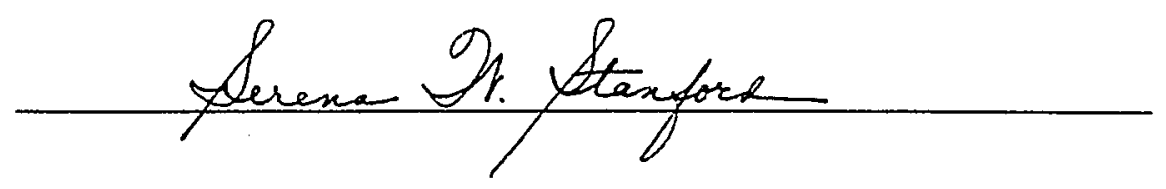




\begin{abstract}
AN ANALYSIS OF THE EFFECT OF STATE AND LOCAL BUREAUCRATIC REGULATION ON THE VIABILITY OF SMALL BUSINESS WITHIN SANTA CLARA COUNTY

by Leslee Allyson Brady

This thesis addresses the effect of bureaucratic regulation on the viability of small businesses located within Santa Clara County, California. It examines the history of small business in America and seeks to explain why this small business sector has diminished.

It seeks to understand how many small businesses can lead to monopolistic competition. Competition where many vendors are providing a product slightly differentiated from the next.

It studies the regulations affecting small business at the state, county, and city level and seeks to show how to alleviate this burden from small businesses.

A survey of owners of small businesses in Santa Clara County provided a focus of the difficulties encountered by these entrepreneurs in their dealings with the state and local governments. From this survey and the research, it was determined the affect of regulation depends upon the size of the business and the industry in which it is located.
\end{abstract}




\section{ACKNOWLEDGMENTS}

My sincere thanks to all the business owners who completed my survey on small business regulation in Santa Clara County. Their answers helped to provide direction for my study. Thanks also to the employees of each city and the local Chambers of Commerce who assisted me in obtaining materials or providing alternate resources.

Thanks to my parents for their support while I pursued my goal of returning to school to obtain my Master of Arts degree in Economics. I especially thank my mother for her constant encouragement and time spent in proofreading.

Thanks finally to my fiance, David Lageschulte, for always being there when I needed him, for his understanding and encouragement, and for his help with my many other responsibilities and chores. 


\section{TABLE OF CONTENTS}

LIST OF TABLES

........ vi

Chapter

1. Introduction $\quad \ldots \ldots . .1$

2. Smail Business $\quad$....... 5

3. California State Laws Affecting Business $\quad \ldots \ldots . .13$

4. Santa Clara County Laws Relating to Business $\quad$........ 18

5. Local (City) Laws Affecting Business $\quad$....... 20

6. The Small Business Owner $\quad$....... 27

7. Small Business Advocates $\quad$........ 34

8. Policy Suggestions regarding Small Business $\quad$........ 39

NOTES $\quad \ldots \ldots . . .43$

BIBLIOGRAPHY $\quad$....... 46

APPENDICES:

APPENDIX A 49

APPENDIX B

….... 51

APPENDIX C

....... 55 
LIST OF TABLES

TABLE 1

Respondents' Characteristics

29-30 


\section{Chapter 1}

\section{INTRODUCTION}

In the American economy, small business and industry remain the rule rather than the exception. For every big business, there are about fifty small ones; the healthier they are, the stronger and more competitive the United States economy. Business economists generally agree that small businesses employ over half the nation's nongovernment work force. In recent years, small independent businesses were the prime source of employment growth in the United States while larger firms were redistributing rather than creating employment. Collectively they contribute about forty-eight percent of the total business output and generate over forty percent of the nation's gross national product 1 .

Until only several decades ago, America was being built on this foundation of small business. Emigrants flocked to this country, many with skills or knowledge of family-operated businesses. These individuals began enterprises in America, often employing family members and other new citizens. Because life was generally contained in smaller communities, these establishments flourished. They catered to the needs of the local residents by being in convenient locations. If not for scale economies, every street corner might still have its own conveniently located grocer, pharmacy, lumber yard, etc.

But America is no longer a country confined to these small, tight communities. Freeways, automobiles, and other transit and 
transport opportunities have widened our world. The larger store or establishment has access to resources the small business often cannot utilize due to size limitations. Convenience or selection may lead consumers to purchase at large supermarkets or department stores. Larger businesses usually can operate in a more cost effective manner due exclusively to their size. They can tap markets unavailable to the small firm because of volume.

However, small firms provide a source of competition to larger firms in their industry, limiting the latter's ability to raise prices and/or be technically inefficient in the use of factors of production.

Small businesses have exhibited a tenacious will to survive in the face of adversity. However, in the United States, the percent of businesses deemed as small is declining. Most small businesses close their doors in less than five years of operation ${ }^{2}$. Some of these are swallowed up by large corporations hoping to gain a larger portion of the market place. Corporations can reduce competition simply through the acquisition of a competing company providing a substitute product. Small businesses do not have the resources to compete against these mighty conglomerates.

Many factors lead to the failure of small business. Some of these are external forces and others come from within the businesses. Among these are insufficient assessment of professional and personal skills, lingering recession, health care costs, rising labor costs, high taxes ${ }^{3}$, inadequate financing, inappropriate location, poor implementation of management, and government regulation. 
According to the Small Business Administration, lack of compliance to government regulations accounts for approximately onethird of business failures in the United States. Regulation is a cost of doing business. It could have both a fixed and a variable cost. The fixed cost is a burden on small firms and could potentially be so high in some businesses as to keep out some people who might otherwise start a business. Or a firm may deliberately stay smaller just to avoid the regulation a larger firm faces.

These regulatory burdens and the subsequent cost of compliance shackle many small businesses by inhibiting growth and productivity. Money spent to satisfy regulations cannot be spent to further the business.

If small businesses provide the workplace for over half the nation's non-government workers, efforts to improve the success of small business should have a direct effect on the economy through the preservation and continual creation of jobs and the profit generated 4 . This study seeks to examine the effect of state and local laws and regulations on the viability of small business in Santa Clara County and how these hinder the success of such businesses.

Within Santa Clara County, there are fourteen incorporated areas. These are Campbell, Cupertino, Gilroy, Los Altos, Los Altos Hills, Los Gatos, Monte Sereno, Morgan Hill, Mountain View, Palo Alto, San Jose, Santa Clara, Saratoga, and Sunnyvale. Of these, Los Altos Hills and Monte Sereno are zoned strictly residential and agricultural; the only businesses allowed within the town limits are those located in the hume. 
Much regulation flows from laws enacted at the federal level. States are required to comply with these regulations and, consequently, legislation is passed requiring cities and counties to be in accordance with these laws.

While there are many federal laws and regulations governing the activities of businesses within the United States of America, this study will focus exclusively on those at the state, county, and city level. By so doing, certain activities 5 are excluded from this study. Patent registration is provided only by the federal government. Also, the Internal Revenue Service is responsible for business federal income taxes, employee income and social security taxes, and other federal taxes.

Due to its extremely controversial nature and possible impending legislation, I have chosen not to address the issue of the provision of health care insurance by businesses. Another area not addressed is that of financing a small business. 


\section{Chapter 2}

\section{SIMALL BUSINESS}

It is widely believed small firms contribute to economic vitality partly by increasing the level of competition in the economy through competing with large firms and partly by providing inputs to large firms, enabling the latter to be competitive in world markets. The smaller firm competes with the larger firm by differentiating its product through either being in a location that is more convenient to customers (many consumers will pay a price premium for a certain amount of locational convenience), offering exceptionally good service, advertising, or in a physical difference of the product supplied. The small local firm is often

more able to provide a specialty product for a particular customer which a larger firm can not accommodate.

Many firms with differentiated products leads to monopolistic competition; this competition arises because of the consumer's desire for variety. It is a market characterized by a large number of producers in which each producer supplies a good slightly different from the competition. Monopolistic competitors are small relative to the market for their general class of differentiated product and entry into their market is free. Firms who differentiate their product will gain some control over the price of their goods; if goods provided by different firms are substitutes, a rise in price of one good can cause the demand for the other to increase.

It is often difficult for the larger firm to produce a differentiated 
product. Money may have been sunk into equipment which can only produce something in one manner. But the larger firm may also have the ability to differentiate its product simply because of its size.

Sometimes, it is the very existence of large manufacturers that provide smaller firms with many of their opportunities. The small firm which manufactures a component of a larger firm's product also stimulates the economy. It becomes a supplier of an intermediate product rather than a producer of a final product.

In the American economy, the small firm sector fluctuates markedly from year to year. Many small firms are begun in the trough of a business cycle when job opportunities are suddenly limited. Or they are begun by entrepreneurs who are dissatisfied with their present job. They don't always start a business because they will make more money. Sometimes the benefit is in being their own boss and having control of their time.

Or sometimes, they leave the company they work for because they have a better idea or process for making something or a better manner in which to provide a service. This birth of a business can lead to job creation if it succeeds. Competition is a big factor - the smaller firm has to have a better idea in order to compete with the larger corporation. The development of a better productive technique can place the small firm at a competitive advantage.

Some small businesses are owned by people who otherwise may not be working. Sometimes a hobby extends into a small business; often this is the case for women who desire to stay home with their 
children or for elderly desiring a way to fill their time.

Small firms are likely to respond differently from large firms to financial and non-financial stimuli such as taxation incentives and other opportunities for expansion. There are certain tax incentives if a company re-invests its earnings to build capital. Generally, this option is not available to the small firm because the profit of the company represents the income of the owner(s).

Entrepreneurs need a favorable tax environment to support innovation and growth. It is important to maintain and extend tax incentives which encourage business to take investment risk. Any money paid out in taxes is money which can not be reinvested in the business. Taxes bear more heavily on a firm that is largely dependent upon internal sources of capital to finance growth.

Larger firms are able to take cash and more readily convert it into capital equipment. A similar percentage size influx of cash into a small business is typically used to pay bills rather than expand. It may not be sufficient to purchase capital equipment necessary for expansion

Most small firms lack market power in both the product market and in the purchase of inputs and so are generally price takers. There is evidence small firms are generally at a disadvantage in terms of raw material prices, ability to hold stocks, lack of brand identification, technical and market information and various management techniques. Because of the amount of raw material purchased, they are ineligible to receive volume discounts from their suppliers. Storage facilities for these materials are usually limited. The smaller firm can not afford to hold a 
large inventory because it ties up their available cash. Consumers faced with uncertainty rely heavily on brand identification to judge quality; it may be difficult for a new firm to sever this attachment. For the larger firm, management is a diffuse process with individuals at different levels having special talents, special interests, and varying amounts of information; because of limited resources this is not available to the smaller business.

On the other hand, they can compensate for these weaknesses: in the economic field by tapping unused resources of labor, meeting special local needs, and stimulating competition ${ }^{6}$. They can utilize local raw materials and serve local markets, eliminating long transport hauls while providing work for local people. The small firm may be a local grocer catering to the nearby residents. Or the product or service supplied may be a substitute for a product provided by a larger firm.

For regulation purposes, a business is defined as a profession, trade, occupation, or all and every kind of calling carried on for profit and livelihood. This does not include organizations run for a religious or charitable purpose or the services rendered by an employee to their employer.

How small is small? This is a very significant problem for those concerned with the formulation and exercise of public policy. A small business is not simply a "scaled down" version of a large business. It has different objectives and different aspirations; it may be seeking only to fill a specific need in a niche market. It faces different problems and responds to different incentives. 
There is no consensus on a definition of small business. Definitions have been based on the number of employees, the gross income of the firm, the method of ownership and management, and numerous other measures of size and business activity. Definitions tend to vary widely across industry. In general, a business where one or more persons have direct control over the management decisions of the firm is classified as small.

Small businesses are relatively labor-intensive and most dominant within retail and service industries. This is not to say raw materials are not important. Many specialize their products and services to exploit niche markets. Often in these niche markets, the larger firm is unable or unwilling to differentiate their product. An example would be a local ethnic bakery. Often the size and volume of these small businesses allow them to differentiate their product to individual customer needs (customization).

Technology has also led to the home-based entrepreneur; 31 million people nationally work from their home ${ }^{7}$. The majority of small businesses are started during the trough of the business cycle rather than any other of its stages. This suggests many Americans go into small businesses when they find other employment options cut off ${ }^{8}$.

A small business may be one of three forms: a sole proprietorship, partnership, or corporation. There are advantages and disadvantages of each. A sole proprietorship is a company owned wholly by one individual. A partnership is owned by two or more people. A corporation must meet several requirements of the state and is owned by people who 
purchase stock in the company; liability is limited and a corporation is an entity in itself.

Unpredictable monetary policy, rapidly changing tax laws, arbitrary regulations, inflation, fluctuations in the value of the dollar and the failure to enforce the laws effectively all tend to discourage investment in the start-up of new businesses.

In order for any enterprise to succeed, it is necessary to start out with sufficient capitalization. Most small businesses are begun with the savings an individual has accumulated. Remembering that most small businesses are labor intensive, many are generated through "sweat" equity and little funding. Loans to small businesses from the banking community are extremely limited and are usually based on the company's financial record over a period of at least five years.

The patent ${ }^{9}$ process can create additional difficulties for small business. As in many other government processes, entrepreneurs need to be educated about the procedures for applying for a patent. Unfortunately, the patent process needs substantial overhauling to ensure that most patents can be granted quickly and infringements can be prosecuted quickly.

For the majority of small businesses, the profit of the company is also the income of the owner. It is estimated the average effective rate of the corporate income tax is fifteen percent higher for small firms than for large. This is attributable to the presence in the tax law of certain opportunities and concessions which are essentially available only to large firms ${ }^{10}$. Examples include accelerated depreciation, investment tax 
credit, the LIFO method of calculating inventory costs, foreign tax credit, and the tax-free exchange of stock. The small business is often limited in its exercise of these options due to sales volume and/or the size of business.

In 1953 to combat this problem, Congress created Subchaper S of the Internal Revenue Code. The main intent was to allow small corporations, which were essentially partnerships, to have the advantages of a corporate form of organization without being subject to the possible disadvantages of the corporate tax structure.

Entrepreneurs also need this favorable tax environment at the state level to support innovation and growth. It is important to maintain and extend tax incentives which encourage businesses to take investment risks. Often the risks taken lead to new products and industry, which lead to the formation of new jobs. This innovation is necessary to keep our nation competitive.

Through legislation, an overall favorable environment can be created to encourage the success of small business. However, due to the size of the enterprise, laws intended to influence or direct larger companies often indirectly inhibit the viability of small businesses. Conversely, there are also incidences where small businesses "fall between the legal cracks" because of their size.

One of the drawbacks for small businesses is they generally lack the expertise to remain abreast of changing laws and compliance regulations. The overall effect of government regulation tends to be regressive, with compliance costs falling most heavily on the smallest 
firms. Because of sheer size, large corporations can either place on staff or hire on retainer individuals with the technical knowledge of the laws affecting their industry. Due to under capitalization, this is usually not an option for smaller firms. 


\section{Chapter 3 \\ CALIFORNIA STATE LAWS AFFECTING BUSINESS}

How does economic policy deter the entry of small businesses and how does it prevent existing small businesses from growing?

There are many vital issues an individual must consider before starting a business. State and local regulations and requirements vary widely according to the business conducted. Some questions an individual needs to consider are:

1. Have you obtained a fictitious name clearance from the county?

2. Do you know the zoning code for your business location? (residential, commercial, or industrial)

3. If a "home occupation," do you know your assessor's parcel number?

4. If you intend to use signs, do you have clearance from the planning department?

5. Will you be distributing advertising leaflets door-to-door or on cars in parking lots? (must obtain Handbill Permit from City Hall)

6. Do you intend to sell used merchandise? (must obtain Second Hand Permit)

7. Do you intend to buy jewelry, gold, silver or scrap iron from the general public? (must obtain Second Hand Permit)

8. Do you intend to sell door-to-door to the general public? (a Peddler Permit is required)

9. Do you intend to make sales from a vehicle? (Peddler Permit required)

10. Do you intend to permit or provide for public dancing on the premises?(check with Police Department)

11. Do you use or store hazardous or flammable materials? These include gasoline. solvents, caustic and waste oil, other than normal household use. (check with Fire Department) 
12. Do you generate any hazardous waste?

13. Do you do any automobile repairs?

14. Do you do any welding or cutting?(check with Fire department)

15. Is your business a wood cutting machine shop or milling operation that produces dust?

16. Do you do any spray finishing (flammable liquid spray finishing)?

17. Do you intend to sell food or beverage?(a Health permit is required)

18. Do you intend to use weighing or measuring devices?(all equipment must be certified by the County Weights and Measures department)

These questions suggest only some of the issues critical to businesses. The entrepreneur may face others depending upon the nature of their business.

\section{CALIFORNIA REGULATION}

Many businesses are regulated at the state level. Included are physicians, attorneys, engineers, land surveyors, and building contractors. Some businesses require both a state and city license for operation. These state licenses are generally limited to occupations requiring extensive training, where public safety or health is involved, or consumer fraud is a problem.

The California Secretary of State handles the registration of corporations, filing of trade and service marks, and articles of incorporation. Any business operating as a corporation must file with the Secretary of State articles of incorporation.

Every person engaged in the business of selling tangible personal property and/or collecting sales tax on that product must apply to the 
State Board of Equalization for a Seller's permit (also called a "resale permit").

The California state department of Business, Transportation, and Housing regulates real estate, alcoholic beverage sales, insurance, banking, savings $\&$ loans, and housing. All businesses selling alcoholic beverages are required to obtain an Alcohol Beverage Control License from this department.

Any business activity regarding the care of children must obtain a license through the state. Periodic inspections of facilities where children are cared for are conducted by the state without prior notice. The grounds on which this child care is provided are subject to strict regulations, including building size and surrounding vegetation allowed.

Building contractors must obtain licenses for all projects costing $\$ 300.00$ or more through the California Contractors State License Board.

The Employment Development Department regulates unemployment, disability and personal income tax and withholding registration. If a business hires employees, it must obtain an Employer's Identification Number (EIN). The business is then required to file a Form DE-1 with the State Employment Development Department, Employment Tax District Office. After filing, the business is then responsible for the withholding and payment of State Payroll tax, Unemployment and Disability tax, and state income tax withholding.

The Labor Commission office in the State Department of Industrial Relations provides information to those businesses hiring employees. For many businesses, state law requires employers to secure workers' 
compensation coverage. Private insurance companies, as well as the state of California, offer this coverage. Because many small businesses are labor-intensive, this is potentially a major expense. Yet the fines and penalties of not providing this insurance are equally exorbitant.

As an incentive to the continuation of a business, current law permits a business buyer to petition the Employment Development Department to acquire the seller's unemployment insurance account. Buyers should take such action if the experience rating of the seller's account would result in a lower tax rate than the rate applicable to a newly registered business.

In addition, all employers are subject to current wage and hour laws and occupational safety and health laws. The raising of the minimum wage to $\$ 4.25$ per hour in 1989 increased the cost of labor for many small businesses.

Business owners should also be familiar with the California Occupational Safety Health Act, which sets down exact requirements for safety and health standards in places of employment throughout the state. OSHA exempts firms employing fewer than twenty employees from its regulations. This is one case where the smaller firm has a regulatory advantage over a larger enterprise. Unfortunately, for many of the businesses affected, Cal-OSHA regulations tend to be confusing and contradictory. Fines for non-compliance can be steep. These regulations can be found in Title B of the California Administrative Code.

The Franchise Tax Board handles proprietor's individual income taxes, partner's individual income taxes, and corporate franchise taxes. 
Any business involved in for-hire carriers transporting property or passengers in intra-state commerce is regulated by the California Public Utilities Commission.

Many agencies (see Appendix C) regulate business in the state of California. Unfortunately, these agencies often do not consider the size of the affected establishment when corresponding legislation is proposed and passed. 


\section{Chapter 4}

\section{SANTA CLARA COUNTY LAWS RELATING TO BUSINESS}

Santa Clara County actually has few laws regulating business. Instead, most existing regulation was enacted at the city level.

If a person chooses to operate a business in the unincorporated area of the county, there is no requirement for a business license per se. A business owner needs to check with the Central Permit Office in the Department of Planning and Development to see if their business is affected by any other legislation. For certain types of businesses, special permits from the Health Department or the County Clerk are required ${ }^{11}$.

Most businesses, whether located in incorporated areas or in the county limits, are required to file a Statement of Fictitious Business Name with the County Clerk's Office within forty days of the start of the business ${ }^{12}$. A fictitious business name is defined in the California Business and Professions Code Section 17900 as a name that does not include the surnames of all owners of a business or, in the case of a corporation, does not include the corporate name. Many banks are now requiring their customers to file a statement, whether legally necessary or not, before the banks will open a commercial account or approve a business loan. A fictitious business name filing expires within five years of December 31 of the year the initial filing was made or when a change has occurred from information in the statement.

After filing a Fictitious Name Statement, a business must publish it once a week for four consecutive weeks in a local paper for the 
statement to be complete. An Affidavit of Publishing must then be filed with the County Clerk within thirty days of the date publishing was completed.

If a business will be selling food, the owner needs to obtain a permit from the Santa Clara County Environmental Health Service. This regulation also applies if part of the business activity involves a public pool or spa. Businesses using or storing any chemicals other than household cleaning items also need to register with the County Health Department.

Santa Clara County Ordinance Code Sections A34-75 through A34-77 require the Department of Weights and Measures to register, test, and certify by the County Sealer commercially used weighing and measuring devices. If a business owner intends to use such devices, they are required to register their device with the Department of Weights and Measures. Period inspections on all devices are routinely performed. Most cities in Santa Clara county require a business to be in accordance with any existing county laws affecting the business. 
Chapter 5

\section{LOCAL (CITY) LAWS AFFECTING BUSINESS}

State law permits cities and counties to license and regulate businesses - not prohibited by other state or federal law - which are carried out in the local jurisdictions, including all shows, exhibitions, and lawful games. The local city hall can provide information on business licenses, building permits, and zoning information. All business locations must be in a zone suited to the type of business that is being conducted. In addition, depending on the location, a development or use permit may be required which could be more restrictive than applicable zoning requirements. It is the responsibility of the individual business owner to contact the planning department in the city of their establishment to learn of these requirements.

In the course of conducting my research, I requested information regarding starting or continuing a business in each city in Santa Clara County. Several cities provided prepared packages. Others directed me to the various departments and agencies within the city.

Some cities require all persons or companies conducting business in the city limits to pay the business license tax, whether or not their business is located within that city. Often businesses falling into the latter category are entitled to an apportioned tax rate.

Business licenses are only issued by incorporated cities. Often, obtaining a business license to begin a business is very difficult. Business license rates and permit requirements vary according to the 
type of business ${ }^{13}$, the number of employees, and the issuing city. All licenses are non-transferable and must be kept posted in a conspicuous place on the premises of a business. Fees are usually based on the number of employees or a flat fee for specific businesses. Usually stated on the license is the name of the person to whom the license is issued, the name of the business licensed, the place where such business is to be transacted and carried on, and the date of expiration of such license. Licenses are generally issued for one year and are renewable in the same month each year which the license was originally obtained. Some cities issue annual renewal notices as a courtesy.

For business purposes, an employee is defined as each and every person engaged in the operation or conduct of any business, whether as owner, member of the owner's family, partner, associate, agent, manager or solicitor, and each and every other person employed or working in such business for a wage, salary, commission or room and board 14 .

There are a wide variety of businesses. Certain activities require additional permits beyond a business license. Alternately, there are some businesses which are required to register with either the United States government or the State of California and in so doing are exempt from city license regulation. This exemption does not necessarily exempt the owner from the payment of applicable local taxes.

A separate license must be obtained for each branch establishment or location of the business transacted. If a person engages in two or more separate businesses at the same location, they must obtain a separate license for each business. 
Many types of retail or office operations can be opened with a simple business license approval. Other activities, because of their location or circumstances, for example, late evening hours, sale of liquor, vehicle storage, or use of hazardous substances, may require formal approval by the local planning commission or city council prior to the commencement of conducting business. Sensitive or controversial business uses can be subject to a rigorous public review process.

Entrepreneurs may need to contact the local Building Department for building permits, safety standards approval, and local codes and inspection. All buildings where business is conducted must meet Fire Code and Hazardous Materials standards as specified by each city.

The following businesses usually are required to obtain fire department clearance prior to commencing operations from any locations: auto body and paint shops, auto brake and tire shops, auto wrecking, car rentals, chemical recycling and recovery, chemical warehouse and manufacturing, contractor and construction companies, dry cleaning establishments, electronics, fertilizer storage, food processing, furniture manufacturing and refurbishing, general warehouse, hospital laboratories, medical centers, metal fabrication and welding, new car dealers, wholesale paint, pest control, plating, pool service and supply, printing, publishing and newsprint, retail gasoline stations, semiconductor manufacturing, and towing/trucking/moving and delivery companies.

Some businesses, such as peddlers 15 opérating catering trucks or ice cream trucks and taxi drivers, must register with the local police 
department ${ }^{16}$. Those required to register and obtain a regulatory permit are businesses easily subject to fraud or other criminal activity. Also, due to their appearance and mobility, many cities in Santa Clara County limit the number of roving vendors transacting business within city limits. These limitation may be good for the vendors because it limits their competition (regulation which limits the entry of firms into a particular industry may lead to queuing; such a barrier to entry is the source of monopoly power and is a reflection of market disequilibrium.)

Business conducted from a home located within city limits does not require a business license in every city in Santa Clara County but may require zoning approval. It is the responsibility of the business owner to contact the local City Hall to determine the requirements of the particular city. There are usually strict limitations on home occupations. They must be conducted entirely within the dwelling property and can employee no one other than the inhabitants of the household. A home occupation must not adversely affect the surrounding residential neighborhood. The placement of signs to advertise and indicate location of the business is severely restricted in residential areas.

Below are some specific regulations or requirements enacted by individual cities in Santa Clara County.

\section{CAMPBELL}

Within the city of Campbell, the Fire Department conducts annual fire inspections. Also, it is up to the business owner to make certain their business location is zoned for their particular type of business. If a 
business is run from the owner's home, a Home Occupation Permit is required from the Planning Department. Home Occupations are permitted for limited types of businesses and must meet various requirements and restrictions.

\section{CUPERTINO}

Cupertino welcomes the establishment of business activities within its limits. In addition to the community care license which must be obtained from the state, Cupertino also requires a Use Permit from the Community Development Department if a business owner is providing day care for more than six children. If an owner intends to advertise their business activity by distributing handbills, leaflets, or solicit from door to door, special permits must be obtained from the Code Enforcement Department at City Hall. To run a business consisting of massage therapy, an owner will need to obtain an application from the city Finance Department at City Hall. In addition, the city's sign ordinance regulates the size, number, and placement of signs for nearly all types of businesses. In many locations mainly those areas zoned for retail or industrial, sign approvals have previously been granted and granting current approval is a simple process.

\section{MILPITAS}

In the city of Milpitas, any applicant for a business license must be fingerprinted. These prints may be used to obtain reports about the individual including, but not limited to, information as to whether the 
applicant has ever been found in violation of a regulation regarding business or has ever been convicted of any crime against property. If the applicant has previously been convicted of a misdemeanor or felony, the city requires the applicant to furnish either a Faithful Performance Bond or a cash security deposit in the sum of $\$ 500.00$.

The license tax collector in Milpitas may also require an applicant for a license for a business to be conducted, in whole or in part, out-ofdoors to post a sum of money as a cash bond in the amount to be determined by the license tax collector to assure the out-of-door premises occupied by the licensee will be left in a state of cleanliness and good order when abandoned by said licensee ${ }^{17}$.

\section{MONTE SERENO}

This town allows no businesses other than those in the home or related to agriculture. Limitations are imposed on home occupations and the displaying of signs to advertise for such. If the occupation meets all the criteria of a home occupation, no business license is required 18 .

\section{SANTA CLARA}

To begin a business within the city limits of Santa Clara, you must pay business tax and fire permit fees if you have a fixed location. A fixed location is defined as a place of business at a particular site regularly kept open, with someone in charge thereof for the transaction of the particular business engaged in during the hours customary to transact such business. 


\section{SAN JOSE}

The city maintains the right to audit the financial records of a business at any time for up to a three year prior period.

\section{SUNNYVALE}

In 1993, President Bill Clinton and Vice-president Al Gore visited the city of Sunnyvale because of the manner in which the city government is organized. Sunnyvale is considered a very progressive city which readily welcomes small business. Unlike most cities in Santa Clara County, here a business license can usually be obtained in one day.

With the many differing regulations in each city, a business owner needs to thoroughly research all applicable registration, licenses, and regulations which pertain to their particular business. Should a company decide to relocate to another city in Santa Clara County, it must be in compliance with the regulations of the new locale. 


\section{Chapter 6}

\section{THE SMALL BUSINESS OWNER}

To learn more of the regulations actually affecting some small businesses within Santa Clara County, small business owners were approached and asked to complete a survey (see Appendix B). The survey sample was chosen randomly; business owners were approached via mutual contact, telephone, mail, and door to door. Over three hundred surveys were sent out. Those who responded are listed in Table 1, Respondents' Characteristics. The survey response was disappointing.

From the survey answers, it was determined which regulations most hindered the start or success of small business in this county. It would be difficult to address all the respondents' answers; instead the focus is on the regulation affecting most small businesses or severely affecting a few companies.

There are many things to consider when starting or running a business - financing, taxes, permits, regulations and more. Prior to starting a business, a person needs to thoroughly research those areas of regulation affecting their desired business. It is recommended the owner take a small business class offered at several of the local community colleges. Increasing knowledge and understanding of the economic and business principles upon which solid business decisions are based is necessary for the success of the small business. Owners should have a business plan which should include what the company plans to sell, who its competition is, and what its anticipated cash flow and expenses will 
be over the next few years. In most cases, the success of a business is determined well before the doors open.

It is also the responsibility of the business owner or manager to stay abreast of changing laws and regulations. In my survey, several owners cited this as a major concern.

The businesses surveyed often indicated regulation as a hindrance to viability and success; none indicated that it increased their business. Included in this regulation is the increasing costs of insurance, including state workers' compensation insurance ${ }^{19}$. An interesting point to note is that while regulation may affect some businesses negatively, for others it can mean an increase in their business. James Noyes, an accountant in Cupertino, cites the ever changing tax laws and their complexity as a reason for much of his business. Regulation of business has increased the necessity for his services. Yet he is also an example of how a smaller firm can fall through the regulation "cracks." He stated he does not have a business license because it got lost in the bureaucracy.

Audrey Williams of Specific Plating Company stated prior to 1980 there was little regulation affecting her business. Since then a monitoring program has been implemented by the state. Because of the strict regulation instituted, compliance is virtually impossible.

Other regulations greatly affecting businesses are those put out by the California Occupational Safety and Health Administration. Having and maintaining facilities in compliance with such regulations can place a tremendous financial burden on small companies employing more than twenty people. 
Table 1 RESPONDENTS' CHARACTERISTICS

\begin{tabular}{|c|c|c|c|c|c|c|c|c|c|c|c|c|c|c|c|c|c|c|c|c|c|c|c|}
\hline 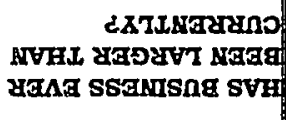 & $z=$ & $=z$ & & $z$ & $=z$ & & $z$ & & $z=$ & & $z$ & $z$ & $z$ & $z>$ & $z$ & $z=$ & $z$ & & $z$ & $z$ & $z$ : & $2=2$ & 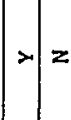 \\
\hline $\begin{array}{l}\text { SNOILYDOT } \\
\text { so agarany }\end{array}$ & 7 & - & & & - & & - & -1 & & & - & - & & $-\curvearrowleft$ & - & - & - & - & - & - & ה. & - & - \\
\hline $\begin{array}{r}\text { GLFOIHILYGO } \\
\text { aTVSTR }\end{array}$ & & $z$ & & & & & $>$ & & $z=$ & & & & & $z=$ & $=$ & $z=$ & 12 & & $z$ & $=$ & $x=$ & 2 & $z$ \\
\hline 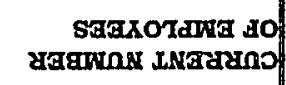 & & -7 & & & & & & & -0 & 0 & $\circ$. & 0 & o & $\rightarrow=$ & - & is - & $\infty$ & - & N - & & \pm 0 & 0 & in $=$ \\
\hline 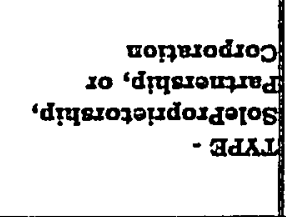 & & 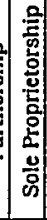 & 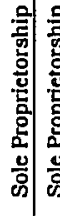 & 辜 & 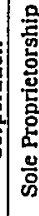 & : & 苟 & 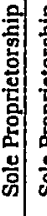 & 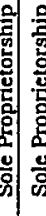 & 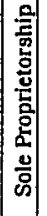 & 氡: & : & 일. & 商 & 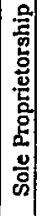 & 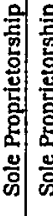 & 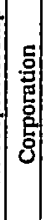 & 鮛 & 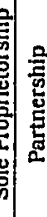 & 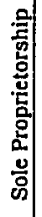 & : & 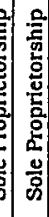 & 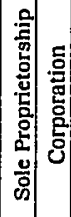 \\
\hline agrsitguLSad & & 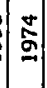 & $\stackrel{0}{0}:$ & : & 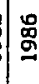 & & & $\stackrel{7}{9}$ & 影 & $\mid$ & $\stackrel{g}{\varrho}$ & ?. & ât? & 䍖 & & 잉: & 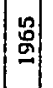 & gू & 5 & & 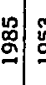 & 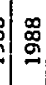 & 照 \\
\hline 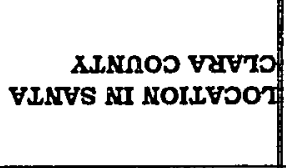 & 淧 & 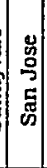 & 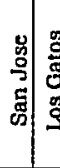 & : & $\overline{\mathrm{z}}$ & 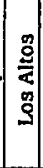 & 妾 & 这 & 煦 & 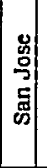 & 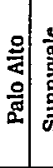 & $\mid \begin{array}{l}2 \\
\frac{2}{2} \\
\frac{0}{2}\end{array}$ & . & : & 瓷 & 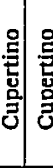 & 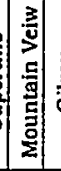 & के & : & & ㅉㅀำ & के & 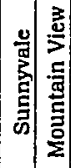 \\
\hline SEanISng do adxy & 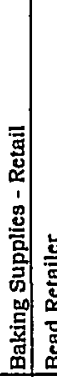 & & 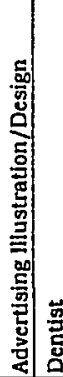 & & 焉 & 总 & 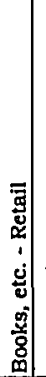 & 递 & , & |ٕ: & 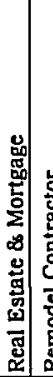 & 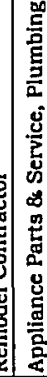 & 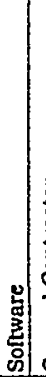 & : & 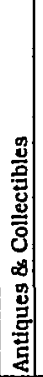 & 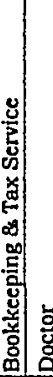 & 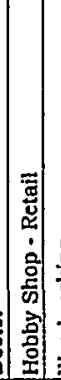 & 衰| & : & & : & 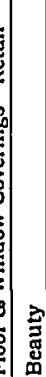 & 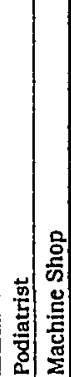 \\
\hline TMVN XRYdWOD & 灰 & : & 密 & $\begin{array}{l}0 \\
0 \\
0 \\
0\end{array}$ & 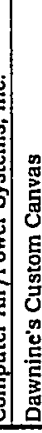 & 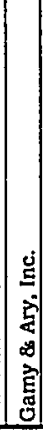 & 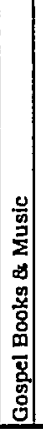 & 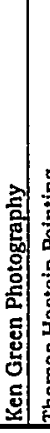 & 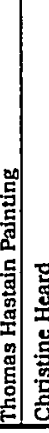 & $\mid$ & 总 & 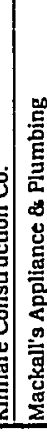 & 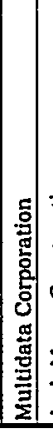 & 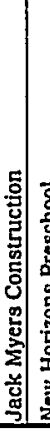 & 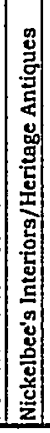 & 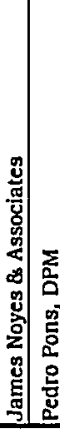 & . & 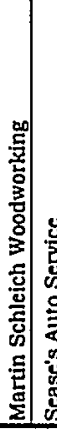 & 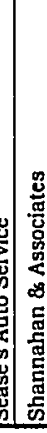 & $\begin{array}{c} \\
0 \\
0 \\
0 \\
0 \\
0 \\
0 \\
0 \\
0 \\
\vdots\end{array}$ & 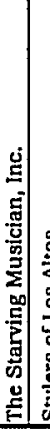 & 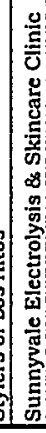 & 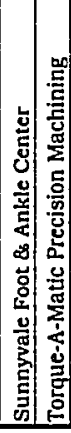 \\
\hline
\end{tabular}


Table 1 con't.

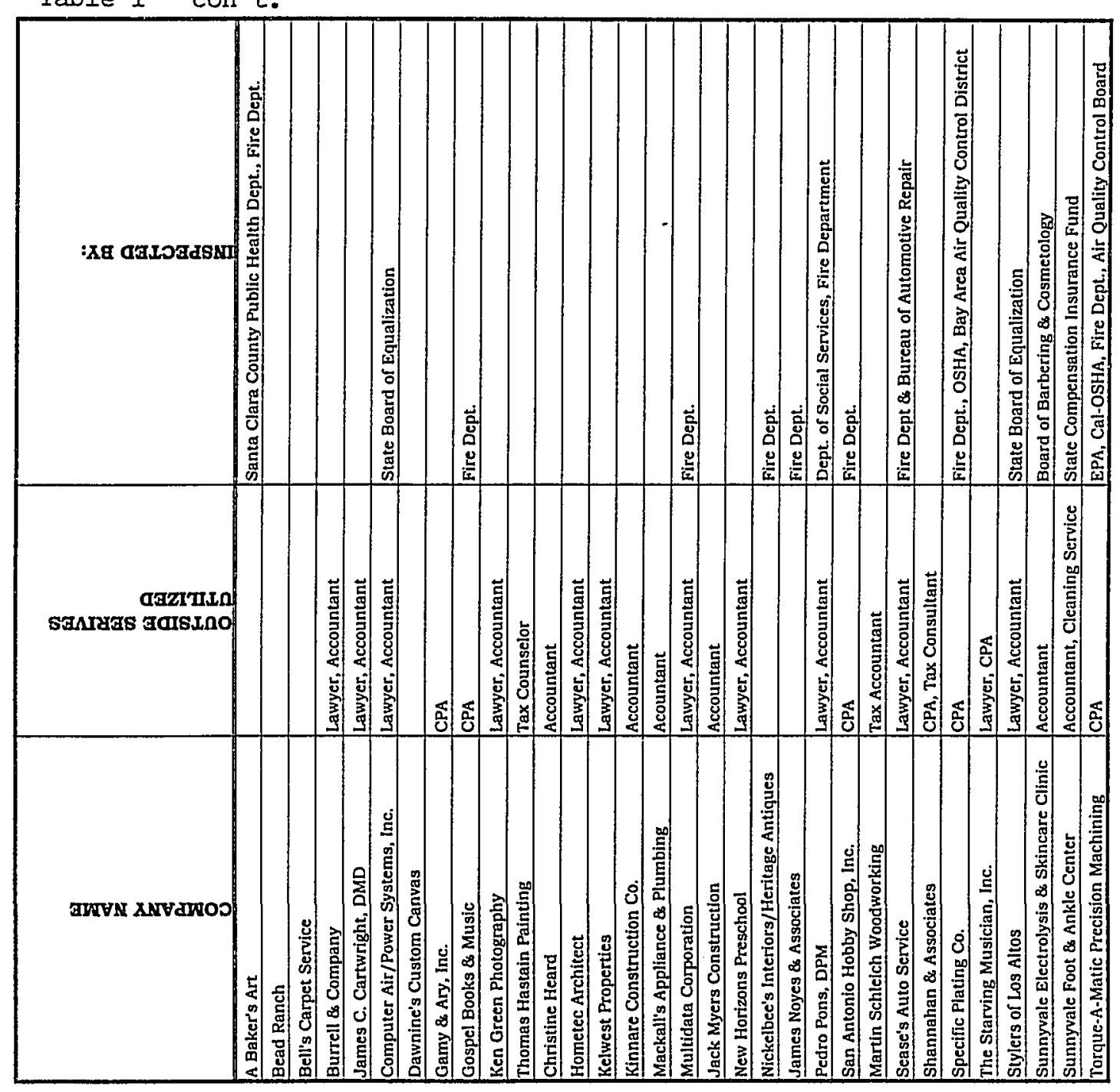


Difficulty in obtaining permits, including time delays and costs, such as building for expansion, has affected some of the surveyed businesses. Moratoriums on construction, either new or remodels, has affected some small businesses such as Rick Hartman's company, Hometec Architects. These moratoriums limit his market.

Several of the surveyed businesses have shrunk their operations. Some sold off sections of their business while others reduced due to recession and declining profits. One stated the overhead cost of maintaining more than one location was simply too high.

Alternatively, for differing reasons, some business owners have chosen not to expand their businesses. The exorbitant costs of insurance and high taxes are one reason. All businesses are required to maintain adequate records to support the figures submitted for taxing purposes for the prior three years. Another reason is the control an owner can maintain over a smaller establishment.

Rather than expand their business through adding more locations or hiring more employees, some owners decided to offer additional services. Some owners do not desire their business to be any larger than the current size. For many, expansion would necessitate the hiring of employees and incurring the additional costs of such an action. For others, expansion could mean diminished control of the company.

Often what hampers the success of a small business is the sheer volume of their business. In speaking with a paint contractor, he told me of the difficulty he has in disposing of used paint thinner. He must dispose properly of the thinner to comply with regulations regarding the 
disposal of toxic waste. If he goes to the expense of purchasing a 55gallon drum and carts it down his driveway to the street, the city of Palo Alto will collect and recycle the thinner. Yet, a full 55-gallon drum is very heavy. How is he to move a full drum? It is something not easily moved without the aid of a machine. Obtaining such machinery is another major expense. It would be most cost effective for him to find an alternative, legal manner in which to dispose of the paint thinner.

Another instance of the effect of toxic materials regulation is the outlawing of certain substances due to tightening of environmental laws. Martin Schleich owns a business in Gilroy doing woodworking, furniture repair and refinishing, and cabinetry. Regulations have removed from the market many finishing products he used. In the future, most of the other sprays and strippers he uses will be banned. Unfortunately, changing laws ${ }^{20}$ regarding toxic waste affect many different types of businesses.

The owner of a picture frame shop in Los Gatos shared with me his frustration in attempting to get funding to expand his business. He feels it is difficult to find an investor (be it bank or otherwise) to invest in a small enterprise. The risk of the business failing is considered too great.

Most banks are unwilling to risk lending money to a start-up firm. The financial institutions desire to see a track record of success before authorizing a small business loan. Venture capital firms usually require the dilution of ownership as a condition of their investment.

Surprisingly, some of the businesses surveyed indicated regulation has had little affect on their business. These tended to be those 
businesses providing a service rather than producing a product.

From the survey conducted, I concluded business owners often encounter difficulty when dealing with the state and local governments. Simply gaining information from these governments regarding regulation can be an arduous task. 


\section{Chapter 7}

\section{SMALL BUSINESS ADVOCATES}

It can not be overly stressed that individuals considering starting a business need to obtain detailed advice on necessary requirements prior to beginning to conduct business. A valuable source is the California Department of Commerce. Also, as a courtesy, some cities have agencies or personnel who will aid an individual. But it remains fully the responsibility of the business owner to make sure they have filed all necessary forms prior to the commencement of their business.

There are numerous resources available to the entrepreneur when questions arise. Many agencies and companies are dedicated solely to the aid of the small business owner. Below is a varied list of such and the services they can provide.

\section{SMALL BUSINESS ADMINISTRATION}

The Small Business Administration is an agency of the United States government created by Congress in 1953 solely to advise and assist the nation's small businesses. It serves small business (1) by lending money, directly or in participation with banks; (2) by licensing, regulating, and helping to finance privately owned small-business investment companies; (3) by helping small business secure a fair share of government contracts and surplus government property; (4) by providing information and assistance in the field of management; (5) by assisting small businesses which are victims of disasters; (6) by 
developing and presenting helpful material in the foreign-trade field; and (7) by providing production and products assistance. In these ways, the SBA acts as an advocate for small business 21 .

In California, the Small Business Administration guaranteed $\$ 245.8$ million in loans during the first quarter of 1994 , an increase of 41.7 percent over last year 22 . The Small Business Administration also frequently offers day-long workshops for potential business owners.

In addition to the SBA, the National Federation of Independent Business, the National Small Business Association, the local Chamber of Commerce, and state Industrial Development Agencies are ready sources of help.

\section{SMALL BUSINESS REGIONAL DEVELOPMENT CORPORATION 23}

In addition to information regarding the conducting of business, small business regional development corporations of California offer special loan programs for hazardous waste reduction, energy costs, and replacement of underground storage tanks to companies needing to be in compliance with existing regulations.

\section{CALIFORNIA DEPARTMENT of COMMERCE, OFFICE Of SMALL}

\section{BUSINESS}

This department of the California state government is an excellent source for licensing information and referral assistance. The office also provides numerous publications concerning small business. The office provides management and technical assistance primarily through 
California Small Business Development Centers located throughout the state. Business information available from these centers covers initial start-up requirements, composing a business plan, financing options, marketing, employee and business insurance, manufacturing and retention, and more.

\section{SMALL BUSINESS DEVELOPMENT CENTERS}

Located at Gavilan College in Gilroy and in downtown San Jose, the Small Business Development Centers are dedicated to assisting with the establishment of businesses and helping them to develop and expand. It is partially funded by the U. S. Small Business Administration. Conferences and training seminars designed to meet the needs of small business owners and individuals interested in starting a business are offered throughout the year.

\section{S.C.O.R.E.}

The Service Corps of Retired Executives offers services designed to aid business owners in the running of their businesses. It is a volunteer group that provides business advice and occasional workshops for potential business owners.

\section{CHAMBER OF COMMERCE}

The California Chamber of Commerce puts out literature geared directly to the business owner. This information is assembled in packets and made available through the local branch of the Chamber of 
Commerce. Three different prepared kits are available pertaining to sole proprietors/partnerships, corporation, and those businesses hiring employees. Each kit contains many federal and state government forms, plus many local government requirements.

The local Chamber of Commerce is interested in promoting and enhancing the business environment and economic climate of the local community. To assist owners in promoting their business, meet other business owners, or to make valuable contacts in the community, the local Chamber of Commerce generally offers a wide variety of services and activities. It would be advantageous for any business owner to join the local Chamber.

\section{INCUBATORS}

There are seven business incubators located within Santa Clara County. An incubator reduces a start-up company's overhead costs by offering low rent and shared support services. They allow entrepreneurs to concentrate on their business without having to worry about the expense of individual services.

\section{INTERNAL REVENUE SERVICE}

The Internal Revenue Service offers small business workshops to explain federal filing requirements to employers.

It is suggested business owners consult with an attorney before commencing business. The attorney can be an advocate for the owner 
and should be able to provide counsel regarding the liability of the business and the owners. 
Chapter 8

POLICY SUGGESTIONS REGARDING SMALL BUSINESS

Entrepreneurs are important because in large numbers they provide an economy with its variety, flexibility, and dynamism. They make an investment in their business, thus stimulating the economy. The purpose of this study was to define the advantages of these small business and suggest how regulation deters the entry of small businesses into industries and how existing small firms are prevented from expanding. Many of the agencies and regulations affecting small businesses in Santa Clara County were reviewed in this paper.

There are many costs of doing business. One cost to a firm is finding a "place" to transact business. There is the cost of gaining information about the market. There is also the cost of simply making transactions and maintaining an inventory.

Although it can also provide some benefits, regulation is generally a cost of doing business, a cost often passed on to the consumer. It is also a cost which is often difficult to measure in economic terms. For the smaller firm with fewer customers, the burden per customer is greater than for the larger firm with many customers. Consequently, the cost per unit of output is higher for small firms.

There are so many agencies with which different businesses must comply. Often regulations and laws are obscure. New regulations and laws constantly go into effect and it is the responsibility of the business to remain apprised of these changes. Occasionally, this government 
regulation can lead to monopoly positions when barriers to entry are high.

Regulations need to be designed to be easily understood and adhered to by all businesses. To the small business owner, costs are increased due to understanding, complying, and filing all money and returns related to regulations from bureaucracies by which they are governed. Often the failure to comply with certain ordinances is a misdemeanor violation and may also subject the business owner to monetary penalties.

First and foremost, there needs to be uniformity in the regulations across cities within a county. This will make it easier for a business to either relocate or expand into a different city within the county. The state also must require its agencies to perform an analysis of the impact any proposed regulation would have on small business and adopt administrative rules which minimize the negative and reflect the special needs and problems of small businesses.

There also needs to be a way business owners can cut through the red tape involved in the establishment and running of an enterprise. A small business owner often lacks the resources necessary to be aware of changing laws and regulations and how these changes can affect their business. It is, perhaps unfortunately, up to the owner to remain informed.

Remember, it is not always external forces which hinder a business' growth; sometimes it comes from internal forces. A majority of responsibility for the success of a business falls on the shoulders of the 
owner. Realistically, a person considering starting a new business or purchasing one in existence needs to learn all laws and regulations relating to their business. This research may be time-consuming but is necessary. As stated previously, there are many resources available to the entrepreneur willing to seek counsel on a particular business.

For many years, the federal government has recognized small businesses as the engine that drives the American economy. This same recognition needs to be apparent at state and local levels. The state of California and the cities in Santa Clara County need to follow the federal government's lead and make allowances for the limited resources of the small business operators. The state needs to create a more attractive environment for businesses, and to encourage the development of innovative new businesses within the state rather than attempting to attract firms from outside the state.

Recently, interest in small firms among politicians and public policy-makers has increased. The Regulatory Flexibility Act passed in 1980 encourages federal agencies to impose lighter regulatory burdens on smaller businesses than on larger ones. This effectively created tiers of regulatory burdens according to the size of firms. Externalities, both positive and negative, are created by policies designed to assist small businesses. The prime thrust of current public policy toward small business has been to reduce the operating costs of small firms on the assumption this will lead to increased profits, which in term will lead to additional workers being employed.

Policies need to be designed that both raise the rate of new firm 
formation and reduce the perceived obstacles to business expansion. It is unclear whether economic growth in our nation induces the creation of many small firms or whether the presence of many small firms is an inducement to economic growth. When one considers that small businesses are scattered across the country, it is easy to imagine the effect that business success or failure has on all the nation's communities. 


\section{NOTES}

${ }^{1}$ Edgar A. Persons, Helping Small Businesses Make It (New York: American Vocational Association, 1978), 3.

2The Small Business Administration says $63 \%$ of new businesses fail within their first six years of operation.

3From 1982 to 1989 , small businesses typically enjoyed a slight decline in the per-employee dollar total of employment taxes, indirect business taxes such as sales and excise levies, compliance costs for environmental regulations, and changes in wage costs. But from 1989 to 1992, the government burden per worker increased 34\%. Most of the increase in the business's burden was due to the 1989 minimum wage increase, the 1990 Americans with Disabilities Act, the 1990 amendments to the Clean Air Act, and the 1991 Civil Rights Act.

${ }^{4}$ Many jobs have become obsolete due to technological advances often introduced by the small entrepreneur.

5 Such as those involving import or export of goods, interstate commerce or transportation, radio and television station construction, meat products, investment counseling, mail order, drugs, and clothing and packaged goods.

6Jonathon Boswell, The Rise and Decline of Small Firms (London: George Allen \& Unwin, Ltd., 1991), 12.

7Sherri Eng, "Small Firms are Big on Optimism - and Creating Jobs," San Jose Mercury News, 18 May 1994, sec. H, p. 3.

8Miansel G. Blackford, A History of Small Business in America (New York: Twayne Publishers, 1991), 85.

${ }^{9}$ The same holds true for trademarks and copyrights.

10David J. Storey, ed., The Small Firm (New York: St. Martin's Press, 1983), 28.

${ }^{11}$ These types of businesses include auctioneering, door-to-door selling, massage parlors, secondhand dealers, taxi service, private 
security services, kennels, quarries, automobile wreckers, and junk yards.

12Fictitious business name following is not applicable to nonprofit groups and certain specified real estate unincorporated investment trusts.

13Some professions requiring state licenses are accountancy, architects, attorneys, auto repair, barbers and beauty operators, collection and investigation, contractors, physicians and dentists, electronic or appliance repair, engineers, geologists, land surveyors, pest control, and shorthand reporters.

\section{${ }^{14}$ San Jose City Code, Section 4.76.060.}

15Roving vendors fall into a category separate from home or storefront businesses and are, thus, treated differently. Each city in Santa Clara County limits the number allowed to operate in each city.

16 Some other businesses which must register with the police department are circuses and carnivals, pawnbrokers and secondhand dealers, pool halls, bingo parlors, massage parlors, public dancehalls, canvassers of periodicals, tow-car businesses, peep show establishments, christmas tree and pumpkin lots, and going out of business sales.

17Milpitas City Code, Ordinance No. 76, Section 1-10.03.

18Monte Sereno City Code, Section 7-1.34.

${ }^{19}$ Many of the surveyed businesses cited workers' compensation insurance rates as a major concern.

20 Many of these laws and regulations are enacted through the Environmental Protection Agency.

${ }^{21}$ Not all businesses are eligible for loans from the Small Business Administration - newspapers, radio and television stations, and liquor stores are not.

22Eng, 3. 
${ }^{23}$ State of California, Everything You'll Ever Want to Know about Running a Small Business. (Sacramento: State of California, 1992), 3. 


\section{BIBLIOGRAPHY}

Acs, Zoltan J., and David B. Audretsch. "Innovation in Large and Small Firms: An Empirical Analysis." American Economic Review 78 (September 1988): 678-90.

Acs, Zoltan J., and David B. Audretsch. "Innovation, Market Structure, and Firm Size." Review of Economics and Statistics 69 (November 1987): $567-74$.

Acs, Zoltan J., and David B. Audretsch. Innovation and Small Firms. Cambridge, MA: MIT Press, 1990.

Anderson, John B. The American Economy We Need. New York, N.Y.: Atheneum Press, 1984.

Baumback, Clifford M. How to Organize and Operate a Small Business. Englewood Cliffs, N.J.: Prentice Hall, Inc., 1988.

Bernick, Michael S. Inner City Business Loan Funds in California. Sacramento, CA: Joint Publications Office, 1991.

Berthoff, Rowland, "Independence and Enterprise: Small Business in the American Dream," In Small Business in American Life, ed. Stuart Bruchey (New York: Columbia University Press, 1980), 29.

Birch, David. Job Creation in America: How Our Smallest Companies Put the Most People to Work. New York: Free Press, 1987.

Blackford, Mansel G. A History of Small Business in America. New York: Twayne Publishers, 1991.

Boswell, Jonathan. The Rise and Decline of Small Firms. London: George Allen \& Unwin, Ltd., 1973.

Botkin, James, Dan Dinamcesuu, and Roy Stata. The Innovators. New York, N.Y.: Harper \& Row, 1984.

Cahill, Jane. Can a Smaller Store Succeed? New York, N.Y.: Fairchild Publications, Inc., 1968. 
State of California, Everything You'll Ever Want to Know about Running a Small Business. Sacramento: State of California, 1992.

Sherri Eng, "Small Firms are Big on Optimism - and Creating Jobs," $\underline{\text { San }}$ Jose Mercury News, 18 May 1994, sec. $\mathrm{H}$.

Fitzroy, Felix R. "Firm Size, Efficiency, and Employment." Small Business Economics 1 (1989): 75-80.

Giaoutzi, Maria, Peter Nukamp, and David J. Storey, eds. Small and Medium Size Enterprises and Regional Development. London: Routledge, 1988.

J. K. Lasser Tax Institute. How to Run a Small Business. New York, N.Y.: Simon \& Schuster, 1989.

Judd, Richard J., William T. Greenwood, and Fred W. Becker. Small Business in a Regulated Economy: Issues and Policy Implications, Westport, CN: Quorom Books, 1988.

Paradis, Adrian A. The Small Business Information Source Book. White Hall, VA: Betterway Publications, Inc., 1987.

Persons, Edgar A. Helping Small Businesses Make It. New York, N.Y.: American Vocational Association, Inc., 1978.

Ross, David P. and Peter J. Usher. From the Roots Up. Croton-onHudson, N.Y.: The Bootstrap Press, 1986.

Small Business Administration. State Policies and Programs to Enhance the Small Business Climate. Washington, D.C.: United States Small Business Administration, 1984.

Stevens, Mark. The MacMillan Small Business Handbook. New York, N.Y.: MacMillan Publishing Co., 1988.

Storey, David J. Entrepreneurship and the New Firm. London: Croom Helm, 1982.

Storey, David J. ed. The Small Firm. New York, N.Y.: St. Martin's Press, 1983. 
Storey, David, Keasey, Kevin, Watson, Robert and Wynarczyk, Pooran. The Performance of Small Firms. Wolfeboro, N.H.: Croom Helm, 1987. 


\section{APPENDIX A}

CHAMBERS OF COMMERCE LOCATIONS IN SANTA CLARA COUNTY

\begin{tabular}{|c|c|}
\hline CAMPBELL & $\begin{array}{l}1628 \text { West Campbell Avenue } \\
\text { Campbell, CA } 95008-1535 \\
\text { (408) 378-6252 }\end{array}$ \\
\hline CUPERTINO & $\begin{array}{l}20455 \text { Silverado Avenue } \\
\text { Cupertino, CA } 95014 \\
\text { (408) 252-7054 }\end{array}$ \\
\hline GILROY & $\begin{array}{l}7471 \text { Monterey Street } \\
\text { Gilroy, CA } 95020 \\
\text { (408) } 842-6437\end{array}$ \\
\hline LOS ALTOS & $\begin{array}{l}321 \text { University Avenue } \\
\text { Los Altos, CA } 94022 \\
\text { (415) } 948-1455\end{array}$ \\
\hline LOS GATOS & $\begin{array}{l}50 \text { University Avenue } \\
\text { Los Gatos, CA } 95030 \\
\text { (408) } 354-9300\end{array}$ \\
\hline MILPITAS & $\begin{array}{l}75 \text { South Milpitas Boulevard } \\
\text { Suite } 205 \\
\text { Milpitas, CA } 95035 \\
\text { (408) } 262-2613\end{array}$ \\
\hline MORGAN HILL & $\begin{array}{l}25 \text { West First Street } \\
\text { Morgan Hill, CA } 95038 \\
\text { (408) 779-9444 }\end{array}$ \\
\hline MOUNTAIN VIEW & $\begin{array}{l}580 \text { Castro Street } \\
\text { Mountain View, CA } 94041 \\
\text { (415) 968-8378 }\end{array}$ \\
\hline PALO ALTO & $\begin{array}{l}325 \text { Forest Avenue } \\
\text { Palo Alto, CA } 94301 \\
\text { (415) } 324-3121\end{array}$ \\
\hline
\end{tabular}


APPENDIX A (continued)

SAN JOSE

180 South Market Street

San Jose, CA 95113

(408) 291-5250

SANTA CLARA

2200 Laurelwood Road

Santa Clara, CA 95054

(408) 970-9825

SARATOGA

20460 Saratoga-Los Gatos Road

Saratoga, CA 95070

(408) 867-0753

SUNNYVALE

499 South Murphy Avenue

Sunnyvale, CA 94086

(408) $736-4971$ 


\section{APPENDIX B}

\section{SMALL BUSINESS SURVEY}

Please take the time to fill out your answers completely. All questions relate to your business and any state or local regulations. Should you run out of room, please finish your answers on additional sheets of paper. This information is confidential and is for my use only in writing my thesis. Should you have any questions, I can be contacted at (415) 813-9117. This survey needs to be returned to me in the included envelope no later than February $28^{\text {th }}$. I thank you in advance for your time and effort. Allyson Brady

Your Name

Business Name

Business Address

Business Telephone

Are you a Sole Proprietor, Partnership, or Corporation?

When were you established?

If a sole proprietorship or partnership, is the owner(s) also the manager(s)? Yes No

If a corporation, when were you incorporated?

Nature of business

The following two questions are asked to determine whether your business falls within the small business criteria I am using for my thesis:

Number of Employees

What was your gross sales dollar amount for the last year?

Did you experience difficulty in obtaining a business license? If so, what was your difficulty?

Yes No 


\section{APPENDIX B (continued)}

Do you have a resale certificate? Yes No

Do you have more than one location? Yes No

If so, please indicate the addresses of all locations within Santa Clara County.

Have you ever been larger or had more branches than you do currently? Yes No If so, what was the reason for your business contraction?

Do you use an outside lawyer, accountant, or other professional service? Yes No

If so, what is the service provided?

Is your payroll processed in-house or by an outside service?

In-house __ Outside service

If so, why did you choose to utilize this service?

What is your state unemployment (payroll) tax rate?

Are all your employees or family members working for the company covered by workers' compensation laws?

Yes No

Have you ever been inspected? __ Yes __ No

If so, by whom or what agency? 


\section{APPENDIX B (continued)}

Have you ever applied for a business loan? __ Yes __ No If so, what was the purpose of the loan?

\begin{tabular}{l}
\hline \\
\hline If so, to whorn have you applied? \\
\hline \\
\hline Was your loan request granted? - Yes - Yes $\_$No \\
If yes, were the terms favorable? \\
Please describe terms
\end{tabular}

If not, from where did you obtain your needed funds?

Who would you define as your competition?

Who are your suppliers and are they also small firms?

Who are your customers?

Overall, what do you see as your greatest obstacle to viability, success, and expansion? 


\section{APPENDIX B (continued)}

How has regulation at the city, county, or state level affected your business?

How have the ever changing tax laws affected your business?

Has your business ever been the recipient of a state tax deferral or incentive?

ב-1

Do you file any other returns other than the requisite state income tax return with the state of California? Yes No

If so, what returns do you file?

Who is your advocate (who do you contact when you have questions regarding your business)?

Do you have any dealings with the Small Business Administration?

Yes _ No

If so, in what capacity?

Are you a member of any small business association?

Yes — No

If so, what is the association?

ciation? Yes No No

Would you care to receive a copy of my final thesis? Yes _ No 


\section{APPENDIX C \\ GOVERNMENT AGENCIES REGULATING BUSINESS \\ (Partial list only)}

\section{COUNTY AGENCIES}

County Assessor

County Clerk

County Consumer Affairs

Environmental Health Service

Central Permit Office

County Recorder

County Weights and Measures

\section{STATE AGENCIES}

Alcoholic Beverage Control

Automotive Repair Bureau

Community Care Licensing

Contractor's License Board

Department of Corporations

Department of Education

Employment Development Department

State Board of Equalization

Bureau of Electronic and Appliance Repair

Franchise Tax Board

Health Services Department

Department of Industrial Relations

Licensing and Certification Division

Department of Motor Vehicles

Public Utilities Commission

Secretary of State

State Department of Consumer Affairs

Examiners of Veterinary Medicine 